\title{
WANDERING IN SEARCH OF QUALIFICATION \\ OF THE ACTIONS IN CRIMEA AND IN THE EAST \\ OF UKRAINE (2014 - 2018)
}

\section{БЛУКАННЯ В ПОШУКАХ ОЦІНКИ ДІЯНЬ В КРИМУ І НА СХОДІ УКРАЇНИ (2014 - 2018 РОКИ)}

\section{Mykola Rubashchenko ${ }^{1}$}

DOI: https://doi.org/10.30525/978-9934-588-15-0-86

Abstract. The article examined the evolution of the normative legal evaluation of armed conflicts that took place in the Crimea and in the east of Ukraine, which are continuing today. The evaluation of these events directly correlates with the qualification of the actions of participants in these conflicts. The study covers a five-year period from 2014 to 2018. The research methodology is based on an analysis of legislative changes, political decisions and measures of Ukrainian diplomacy. The generalizations made on the basis of such an analysis are projected on to the actual practice of the investigating authorities and the judiciary. In this case, statistical indicators are taken into account. The study focuses on the distinction between the international and national aspects of the events evaluation. While at the international level, Ukraine called for a one-way evaluation of the events and their participants in the international armed conflict that was initiated by Russia, then at the domestic national level, after the annexation of Crimea and the beginning of the conflict in the East, the legal system of Ukraine was in a difficult position. The national legal system was not able to build a plan of action in a timely manner, take adequate measures, understand the essence of the events and unambiguously determine what is happening. Defining a legal evaluation, let alone realistically putting it into practice, was not easy. Prior to the announcement of the «Anti-Terrorist Operation», the acts of the participants of the Crimean annexation and members of the self-proclaimed republics of Donbass qualified as crimes against the state

${ }^{1} \mathrm{PhD}$ of Criminal Law,

Associate Professor of the Department of Criminal Law,

Yaroslav Mudryi National Law University, Ukraine 
(separatism, high treason, etc.). After that, the «Anti-Terrorist Operation» was proclaimed, which took place a little over 4 years. In early 2018, the «Joint Forces Operation» began under the leadership of the military in the occupied territory of eastern Ukraine. Despite the fact that with the introduction of the «Joint Forces Operation», it was finally decided to stick to the line of recognizing the conflict as Russian aggression associated with the commission of numerous war crimes, in practice, the persecution for separatism, terrorism and treason is completely dominant. Therefore, the aim of the study is to show that the dissonance between real legal practice and the vector of evaluation of the conflict as aggression of the Russian Federation is due to objective circumstances. Such circumstances consist primarily in changing the nature of the events, as well as in changing the goals of the parties involved in the conflict.

\section{1. Ветуп}

22 лютого 2014 р. у зв'язку із втечею Президента В. Януковича до Російської Федерації, масовим порушення прав громадян та виходячи 3 крайньої необхідності Верховна Рада України як єдиний представницький орган держави вражаючою більшістю прийняла постанову «Про самоусунення Президента України від виконання конституційних повноважень та призначення позачергових виборів Президента України» [39]. Було відновлено парламентсько-президентську форму правління [40], яку без проведення референдуму чи голосування в парламенті відмінив у 2010 р. Конституційний Суд України. Обрано нового Голову Верховної Ради України, який автоматично почав виконувати обов'язки Президента України [29]. До кінця лютого з призначенням уряду діяльність усіх центральних органів державної влади була відновлена. У цей же час в Криму під керуванням та за підтримки так званих «зелених чоловічків», під якими приховувалися представники російських спецслужб і військових, захоплювалися об'єкти транспортної інфраструктури і зв'язку, адміністративні будівлі, а також блокувалися військові частини Збройних Сил України. Події розвивалися настільки стрімко та неочікувано, що ані український політикум, ані суспільство не повністю розуміли всю серйозність таких дій та їх трагічні наслідки. Уже в середині березня 2014 р. Крим шляхом проведення псевдореферендуму та підписання договору з Російською Феде- 
рацією стає частиною іiі території. Як референдуми, так і приєднання до Росії не були визнані ані Україною, ані міжнародною спільнотою.

Проте такі трагічні для українського суспільства події виявилися лише початком. У березні 2014 р. хвилею прокотилися південними та східними областями України сепаратистсько-орієнтовані акції протесту проти нової центральної влади та обраний нею прозахідний вектор політики. Вони підтримувалися людськими та фінансовими ресурсами з Росії та проходили під шаленим тиском російської пропагандистської машини. Як наслідок почав вимальовуватися давно забутий проект «Новоросія», який повинен був об'єднати південні та східні області України в єдине російсько-орієнтоване державне утворення. 12 квітня 2014 р. російський диверсійний загін взяв під контроль Слов'янськ, Краматорськ та деякі інші населені пункти Донецької області [17]. Стало зрозуміло, чим загрожують ці події. У ніч 312 на 13 квітня Рада національної безпеки і оборони України ${ }^{1}$ прийняла безпрецедентне в новітній історії України рішення про проведення широкомасштабної Антитерористичної операції (АТО), про що був виданий Указ [37] виконуючим обов'язків Президента Олександром Турчиновим.

АТО тривала трохи більше 4 років. 314.00 год 30 квітня 2018 року розпочато «Операцію об'єднаних сил» (ООС). Правовою основою нової операції стали Указ Президент України Петра Порошенка, яким введено відповідне рішення РНБО [38]. Порошенко, який водночас є Верховним Головнокомандувачем Збройних Сил України, видав спеціальний наказ «Про початок Операції об'єднаних сил з метою забезпечення національної безпеки та оборони, відсічі та стримування збройної агресії Російської Федерації на територіях Донецької та Луганської області» та затвердив Положення про Об'єднаний оперативний штаб ЗСУ. При цьому глава держави заявив: «Упевнений в тому, щзо ие не просто зміна формату. Це нові можливості захисту української території, украӥнських громадян... Таким чином, з сьогоднішнього дня, 30 квітня 2018 року, широкомасштабна АТО на території Донеиької і Луганської областей завершується. Ми зараз розпочинаємо військову опе-

\footnotetext{
1 Завдання Ради національної безпеки і оборони України, яку очолює Президент України, полягають в консультуванні глави держави щодо питань внутрішньої та зовнішньої безпеки. Рішення Ради набувають сили після підписання Президентом.
} 
рачію під керівництвом ЗСУ для забезпечення захисту територіальної иілісності, суверенітету і незалежності намої держави... Завершення режсиу широкомасштабної антитерористичної операції не позбавляє нас можсливості оголошення АТО в будь-який час, коли виникає терористична загроза на звільнених територіях...» [2].

\section{2. Міжнародний аспект}

Пошуки точної юридичної оцінки подій в Криму та на сході України здійснювалися як на національному, так і на міжнародному рівнях. Боротьба за встановлення однозначної оцінки на міжнародному рівні почалася ще в 2014 р. При цьому Україна використовує усі можливі інструменти. У Європейському суді з прав людини розглядається 5 справ України проти Росії щодо порушення прав людини [43]. Постійна палата третейського суду в Гаазі розглядає позов щодо порушення Російською Федерацією Конвенціії ООН з морського права [44]. Низка приватних та публічних українських компаній судяться також проти Російської Федерації за законом про захист інвестицій в Міжнародному арбітражі [21]. Проте найбільш значущими (а разом 3 тим i найбільш кропіткими) з точки зору оцінки конфлікту та їх геополітичних наслідків є справи в Міжнародному кримінальному суді (МКС) та Міжнародному суді (МC) $\mathrm{OOH}$.

Україна підписала, однак досі не ратифікувала Римський Статут МКС. Спершу первісна перешкода для цього була пов'язана із висновком Конституційного Суду України у справі за конституційним поданням Президента України про надання висновку щодо відповідності Конституції України Римського Статуту МКС (справа про Римський Статут) від 11 липня 2001 року [20]. Конституційний Суд України визнав підписаний від імені України 20 січня 200 року Римський Статут, таким, що не відповідає Конституції України, в частині що стосується положень абз. 10 Преамбули та статті 1 Статуту, 3 якими «Міжнародний кримінальний суд доповнює національні органи кримінальної юстиції. В обгрунтування такого висновку було покладене те, що можливість такого доповнення судової системи України не передбачалась розділом VIII «Правосуддя» Конституції України (абз. 6 пп. 2.1 Висновку). Така можливість була передбачена лише змінами до Конституції України від 2 червня 2016 року, які набрали чинності 30 червня 2019 року [28]. Стаття 
124 Конституції України була доповнена частиною шостою такого змісту: «Україна може визнати юрисдикцію Міжнародного кримінального суду на умовах, визначених Римським статутом Міжнародного кримінального суду». На сьогодні досі не було прийнято закону, спрямованого на реалізацію частини шостої статті 124 Основного Закону.

Незважаючи на це Римський Статут містить у собі механізм, який дозволяє проводити розслідування й за умови, якщо держава не є його учасницею. Згідно ч.3 ст. 12 Римського Статут, якщо існує потреба у визнанні юрисдикції МКС державою, яка не $є$ його учасницею (не $\epsilon$ ратифікантом), ця держава може за допомогою заяви, представленого Секретарю, визнати здійснення Судом юрисдикції щодо даного злочину. Згідно пп. 2 і 3 ч.2 цієї ж статті, МКС може здійснювати свою юрисдикцію, якщо держава, на території якої мало місце вчинення того чи іншого злочину або громадянином якої $є$ обвинувачувана особа, визнала юрисдикцію Суду шляхом подачі заяви, переданої Секретарю, якою вона визнає здійснення Судом юрисдикції відносно такого злочину [41]. Зважаючи на це Україною було визнано юрисдикцію МКС спершу щодо подій на Майдані Незалежності [22], а потім і щодо злочинів, учинених під час подій на сході України та в Криму з 20 лютого 2014 року [31]. Заява про визнання юрисдикції Суду відносно злочинів, що, як припускається, були вчинені на території України в період 3 21 листопада 2013 року по 22 лютого 2014 року, була подана Україною 17 квітня 2014 року. Більше ніж рік потому 8 вересня 2015 року уряд України передав заяву про визнання такої юрисдикції відносно злочинів, що як припускається, були вчинені на території України після 20 лютого 2014 року без кінцевої дати [10, с. 19-28].

Щорічний звіт офісу Прокурора МКС від 2018 р. вже вкотре показує, що справа просувається вкрай повільно, разом з тим, попередня оцінка залишається сталою. Прокурор МКС наразі розглядає три ситуації, стосовно яких потенційно можуть бути порушені кримінальні справи: розстріли на Майдані, події в Криму та конфлікт на сході України.

При цьому стосовно подій на Майдані, то згідно попереднього звіту ще від 2015 р., Прокурор МКС дійшла висновку, що їх можна назвати злочинами проти людства, але поки не наведено жодних доказів того, що насильницьке жорстке застосування сили проти демонстрантів було «систематичним» $\mathrm{i}$ «широким» (§§95-96) [8]. Можна погодитися з О. Сенато- 
ровою, що «це в першу чергу вказує на неадекватність поданих Україною доказів, які, у свою чергу, пов'язані з некомпетентністю правоохоронних органів, які не знають, які докази будуть потрібні для встановлення «широкого» і «систематичного» характеру злочину» [16, с. 10].

Ще у звіті від 2016 року, Прокурор МКС попередньо оцінила ситуацію на території Криму та Севастополя як міжнародний збройний конфлікт між Україною та Російською Федерацією, що виник не пізніше 26 лютого 2014 р., до якої застосовне право міжнародних збройних конфліктів і після 18 березня 2014 року, оскільки в Криму та Севастополі фактично зберігається стан окупації (§ 158) [9]. В останньому звіті за 2018 р. Прокурор МКС продовжує кваліфікувати події в Криму як міжнародний збройний конфлікт, а саму територію називати окупованою, що є правовою основою для аналізу злочинів, вчинюваних в контексті ситуації в Криму в період з 20 лютого 2014 року (§88) [10].

Події на Донбасі попередньо кваліфікуються не так однозначно. Розрізняються дві самостійні лінії: міжнародний збройний конфлікт та неміжнародний (внутрішній) збройний конфлікт. На думку Прокурора МКС, протистояння між урядовими та неурядовими військами на сході щонайменше до 30 квітня 2014 р. досягли такої інтенсивності, яка дозволяє вважати їх збройним (але неміжнародним) конфліктом, а озброєні групи, що діють на сході України, включаючи ДНР та ЛНР, достатньо організовані, щоб розглядати їх як сторони неміжнародного збройного конфлікту. Поряд 3 цим, зважаючи на приклади прямих протистоянь між Україною та Російською Федерацією, паралельно принаймні з 14 липня 2014 р. існує міжнародний збройний конфлікт (§ 72). При цьому продовжується аналіз доказів, які б указували на те, що Росія здійснює «загальний контроль» над антиурядовими групами на сході України, що дозволило б об’єднати ці дві лінії і визнати конфлікт у цілому міжнародним. Однак поки (імовірно зважаючи на недостатність таких доказів) з урахуванням можливості застосування альтернативних класифікацій міжнародного конфлікту/конфліктів на сході України, Прокурор МКС розглядає положення Римського Статуту стосовно як міжнародного, так і неміжнародного конфлікту до злочинів, учинених різними учасниками конфлікту (§ 73).

16 січня 2017 р. Україна також подала позов в МС ООН щодо порушення Росією Міжнародної конвенції про ліквідацію всіх форм расо- 
вої дискримінації та Міжнародної конвенції про боротьбу з фінансуванням тероризму [7]. Україна просить визнати Російську Федерацію відповідальною за конкретні акти тероризму (зокрема за збиття літака рейсу MH17 та обстріл мирних жителів окремих міст) та невжиття заходів попередження. У позові Україна також просила про застосування тимчасових запобіжних заходів, щодо якої МС ООН вже у квітні 2017 видав своє розпорядження. Суд зобов'язав Росію утримуватися від дискримінаційних дій в Криму, однак відмовив у застосуванні заходів в частині фінансування тероризму. Україна наполягає, що незважаючи на те, що на Донбасі відбувається конфлікт, паралельно можна було б застосовувати два правові режими: міжнародне гуманітарне право (право війни) і норми Конвенції проти тероризму [6]. На думку $\mathrm{MC} \mathrm{OOH,} \mathrm{Україна} \mathrm{однак} \mathrm{не} \mathrm{продемонструвала} \mathrm{жодних} \mathrm{намірів} \mathrm{або}$ знань російського керівництва про те, що кошти, які були надані сепаратистам, мали бути використані для здійснення терористичних атак [5]. Розгляд цієї справи продовжується в МС ООН. У червні 2018 р. Україна передала в МС ООН додатково приблизно 6 тон доказів [45].

Міжнародні організації та провідні світові держави також виразили своє ставлення до подій в Україні. Спершу в резолюції Генеральної Асамблеї ООН від 27 березня 2014 р. визнається непорушність території України, і всі суб'єкти міжнародних відносин закликаються до невизнання зміни статусу Автономної Республіки Крим та м. Севастополя [13]. Потім послідовно у своїх резолюціях Генеральна Асамблея ООН не визнала анексію цих територій Російською Федерацією, назвавши їх тимчасово окупованими та закликавши Росію відновити дії законодавства країни на цих територіях [14]. США в т.з. «Кримській декларації» вказують на те, що вони ніколи не визнають окупації Росією українських територій [4]. ОБСЄ у своій Бакинській Декларації закликало Російську Федерацію відмінити анексію Криму [3]. На відміну від Генеральної Асамблеї ООН, Парламентська Асамблея Ради Свропи не лише засудила анексію Криму і Севастополя (тобто дала оцінку не лише Кримським подіям), але й закликала Росію вивести свої війська зі сходу України і припинити надання сепаратистам військової допомоги [11]. «ДНР» та «ЛНР» визнаються самопроголошеними республіками, що діють під ефективним контролем Росії, а їх «органи влади», включаючи «суди», встановлені владою де-факто, нелегітимними відповідно до українського та міжнародного права [12]. 
Можна підсумувати, що юридична та політико-дипломатична боротьба України на міжнародному рівні за 2014 - 2018 роки була відносно успішною. 3 самого початку міжнародна спільнота однозначно засудила анексію Криму та м. Севастополя Російською Федерацією, вказуючи на режим окупації. Менш однозначною $\epsilon$ така оцінка стосовно подій на сході України. У цілому визнається певний вплив Росії на «ДНР» та «ЛНР», однак сам конфлікт не завжди називається міжнародним. Натомість Україна спрямовує всі дипломатичні та політичні зусилля з тим, щоб покласти усю повноту відповідальності на Російську Федерацію як за анексію Криму і фактичну окупацію Донбасу, так і за пов'язані з цим акти насильства.

\section{3. Національний аспект}

Стосовно внутрішньо-національної оцінки, то в політичному вимірі уряд України майже одразу назвав події на півострові Крим та на сході України добре спланованою агресією зі сторони Російської Федерації [див.: 23; 25; 42]. Такі заяви почали з'являтися ще до незаконного референдуму в Криму та його анексії Росією.

3 плином часу почала вимальовуватися єдина картина, що складалася 3 ряду аргументів: окремі висловлювання, що прослизали в інтерв'ю та виступах політичного та військового керівництва Російської Федерації, участь російських найманців, представників спецслужб та військових, поява російської військової техніки, дані прослуховування окремих бойовиків, масштаб пропаганди на російських телеканалах, вихід за межі дислокації військових Чорноморського флоту Росії, що тимчасово згідно договору перебував у м. Севастополь, анексія Криму Росією, видача державних нагород «За повернення Криму» тощо. Разом з тим, усі ці факти 3'являлися поступово в безсистемному вигляді. I хоча вони були достатніми для впровадження санкційної політики США, ЄС та їх союзників, проте самі собою окремо один від одного вони мали опосередкований та слабкий доказовий ефект з точки зору реального кримінального переслідування. Україна крок за кроком з 2014 року збирала докази російської агресії і за заявами керівництва держави продовжує це робити й зараз.

Якщо в міжнародних відносинах складнощі в оцінці подій та їх учасників спричинені зокрема різноманітними геополітичними протистояннями, віддаленістю від подій, що безпосередньо відбуваються, і надмір- 
ною тривалістю міжнародних судових процесів, то у внутрішньому праві України відсутність однозначної оцінки протягом відносно тривалого періоду може цілком закономірно викликати здивування, в тому числі й у західних партнерів України. Більш того така невизначеність, як можна припустити, є однією з причин неквапливості в оцінці цих подій світовим співтовариством (в тому числі судовими установами), та додатковим аргументом на користь позиції Росії. І це зрозуміло, адже здається ніби Українська сторона в особі парламенту, уряду, глави держави та всієї дипломатії просить міжнародну спільноту визнати східноукраїнський конфлікт міжнародним (міждержавним), але в середині країни центральним пунктом $\epsilon$ протидія незаконним угрупуванням, озброєним сепаратистам та терористам, що традиційно вказує на внутрішній характер конфлікту. Вимагається зробити те, що сама Україна поки не робить. Іншими словами, важко не помітити розходження між політичними закликами та реальною правозастосовною практикою. Показники практики цих органів за окремими видами злочинів ілюструє подана таблиця 1.

Таблиця передусім показує різке зростання кількості двох видів злочинної діяльності - «злочинів проти держави» (за КК України - «злочинів проти основ національної безпеки України», передбачених статтями 109 - 114-1 КК) та «терористичних злочинів» (статті 258 - 258-5 КК) у 2014 - 2018 роках, у порівнянні з попередніми роками, що характеризувались відсутністю збройного конфлікту. Так, за 13 років з 2001 по 2013 рік загалом було обліковано 71 злочин проти основ національної безпеки України та 17 терористичних злочинів. При цьому явно простежувалась перевага перших над другими. Разом з тим тільки за перші чотири місяці 2014 року вже було обліковано 112 злочинів проти основ національної безпеки України та 31 терористичний злочин. Унікальною в цьому зв'язку є реєстрація групи злочинів агресії (ст. 437 КК «Планування, підготовка, розв'язування та ведення агресивної війни») та воєнних злочинів (ст. 438 КК «Порушення законів та звичаїв війни»), жоден 3 яких не був зафіксований протягом 2001-2013 років.

Аналізуючи статистичні дані стосовно облікованих злочинів слід розуміти, що кількість осіб, засуджених за їх вчинення та вироки по яких набрали законної сили, є значно меншою. Останнє можна простежити за даними таблиці 2. Незважаючи на це, окреслені вище тенденції при цьому не змінюються. 
Таблиця 2

Кількість осіб, вироки щодо яких набрали законної сили по рокам (за певними видами злочинів) ${ }^{4}$

\begin{tabular}{|c|c|c|c|c|c|c|c|}
\hline \multicolumn{2}{|r|}{ Види злочинів } & 2013 & 2014 & 2015 & 2016 & 2017 & 2018 \\
\hline \multicolumn{2}{|r|}{$\begin{array}{l}\text { Злочини проти національної безпеки } \\
\text { Украйни («Державні злочини»): }\end{array}$} & 1 & 31 & 75 & 59 & 75 & 100 \\
\hline \multirow[t]{3}{*}{ 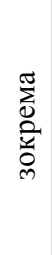 } & \begin{tabular}{|l} 
Посягання на конституційний \\
лад, територіальну цілісність \\
та спроби насильницького \\
захоплення державної влади \\
(Статті 109 і 110 КК)
\end{tabular} & $\mathbf{0}$ & 30 & 58 & 53 & 69 & 83 \\
\hline & Державна зрада (ст. 111 КК) & $\mathbf{0}$ & 1 & 2 & 3 & $\mathbf{0}$ & 8 \\
\hline & Диверсія (ст. 113 КК) & $\mathbf{0}$ & $\mathbf{0}$ & $\mathbf{0}$ & 1 & 4 & 1 \\
\hline \multicolumn{2}{|c|}{ Терористичні злочини: } & 2 & 3 & 17 & 72 & 82 & 104 \\
\hline \multirow[b]{2}{*}{$\begin{array}{l}\frac{\pi}{2} \\
0 \\
0 \\
0 \\
0\end{array}$} & Терористичний акт (ст. 258 КК) & 1 & $\mathbf{0}$ & 1 & 7 & 14 & 9 \\
\hline & $\begin{array}{l}\text { Створення терористичного } \\
\text { об'єднання та/ або участь в } \\
\text { ньому (ст. 258-3 КК) }\end{array}$ & $\mathbf{0}$ & $\mathbf{0}$ & 12 & 59 & 63 & 87 \\
\hline
\end{tabular}

Еволюція оцінки подій на сході України та в Криму та відповідно діянь їх учасників обумовлена передусім поступовою зміною характеру цих подій та відносно повільними темпами вироблення єдиної державної лінії такої оцінки з належним нормативним регулюванням. Ця еволюція зовні радше нагадує хаотичне скитання, чи то блукання, аніж послідовний розвиток. Утім залежно від характеру подій, мети їх учасників та відповідної правозастосовної оцінки, умовно можна виділити три періоди еволюції національної правової оцінки аналізованих подій протягом 2014 - 2018 років: до АТО, в період АТО та після запровадження ООС.

\section{До АТО: сепаратизм $i$ зрада}

До запровадження АТО (по квітень 2014 включно) вчинювані на території Східної України (а також певною мірою Південної України та Криму) діяння оцінювалися переважно як злочини проти національної безпеки (або т.з. антидержавні злочини): державна зрада - 18 справ,

${ }^{4}$ Статистичні дані отримані на основі офіційно опублікованої судової звітності за Формою 6 на Інтернет-потралі «Судова влада України», з якою можна ознайомитися за посиланням: https://court.gov.ua/inshe/sudova_statystyka/ 
посягання на територіальну цілісність і конституційний устрій України - 73 справи. Натомість за статтями про терористичні злочини було почато 31 справу, за злочини агресії та військові злочини - «0» справ. В основі оцінки таких діянь як антидержавних злочинів лежала їх очевидна спрямованість (мета) - змінити межі існуючої території України шляхом відокремлення в самостійне суверенне утворення та подальшим приєднанням до Російської Федерації (чи без такого) без проведення всеукраїнського референдуму ${ }^{5}$. Ця мета проявляла себе в діях щодо блокування та захоплення місцевих органів виконавчої влади, органів місцевого самоврядування, проголошення місцевих референдумів про незалежність від України та їх проведення. Її досягнення відбулося відносно швидко. 7 квітня 2014 р. в будинку Донецької обласної державної адміністрації, прикриваючись правом на самовизначення народів, було проголошено Декларацію про суверенітет «ДНР», засновуючись на територіальних межах Донецької області. 27 квітня була проголошена «ЛНР». 11 травня в само проголошених республіках було проведено псевдореферендум, який за аргументацією керівництва «ДНР», ніби легітимізував їх суверенність. Уже наступного дня незаконні організації «ДНР» ата «ЛНР» оголосили про незалежність.

У короткий період також повністю завершилися анексія Кримського півострову та його юридичне оформлення як складової частини Росії. Як наслідок, 15 квітня 2014 р. Верховна Рада прийняла Закон «Про забезпечення прав і свобод громадян та правовий режим на тимчасово окупованій території України» [30], згідно якого територія Автономної Республіки Крим та Севастополя визнаються тимчасово окупованими внаслідок збройної агресії Російської Федерації, будь-які створені там органи названо незаконними, а їх рішення такими, що не створюють ніяких правових наслідків. Відповідальність за порушення прав громадян покладено на окупанта. I хоча відокремлення Автономної Республіки Крим від України здійснювалося за організаційної, політичної, пропагандистської і навіть військової підтримки Росії, все ж це відбулося відносно блискавично та без прямого збройного протисто-

\footnotetext{
5 Згідно статті 72 Конституції України, межі державної території України можуть бути змінені тільки за рішенням, прийнятим на всеукраїнському референдумі. Цьому кореспондує стаття 110 КК України, згідно якої карається тільки такий сепаратизм, який має на меті змінити межі території України всупереч порядку, передбаченого конституцією України.
} 
яння високої інтенсивності. Тому «кримські злочини» також отримали оцінку переважно як злочинів проти держави (сепаратизм, державна зрада тощо).

\section{Період АТО: боротьба з тероризмом}

На відміну від анексії Криму, конфлікт на сході України все більше загострювався. 3 початку запровадження АТО юридична та політична оцінка як подій на сході України, так і діянь учасників ДНР та ЛНР отримала яскраво виражену оцінку як тероризм: за період 3 травня по грудень 2014 було зареєстровано вже 2022 терористичні злочини і 303 злочини проти держави. Тенденція приблизно п’ятикратного переважання перших над другими зберігалась і наступні роки. Причини цього звісно ж не стільки в тому, що боротьба України з цими видами злочинності отримала офіційну назву «Антитерористична операція», а в зміні характеру, форм злочинної діяльності і трансформації іiі мети. Вона полягала не просто в проведенні незаконних референдумів, облозі урядових будівель та проголошенні декларацій. Спеціально навчені групи російських спецпризначенців та озброєні сепаратисти почали захоплювати місцеві управління поліції та органів безпеки, погрожувати тим, хто не погоджувався з їхніми вимогами, захоплювати заручників тощо. Отримавши військову та фінансову підтримку зі сторони сусідньої держави сепаратисти почали чинити істотний військовий опір проти спроб українського уряду відновити владу на захоплених територіях, здійснювались обстріли цивільних об'єктів за допомогою важкого озброєння, підриви об'єктів транспорту та комунікації, катування та ін. Використання сепаратистами подібних засобів і методів трансформувала характер їх діянь. I хоча антидержавницька спрямованість цих злочинів залишилась, проте найбільшу небезпеку становили вже форми цієї діяльності, що набули терористичного характеру. Крім того, після фактичного захоплення територій, тобто досягнення мети порушення цілісності України, метою самопроголошених «ДНР» та «ЛНР» стало вже утримання цих територій будь-якими методами та протидія антитерористичним підрозділам України. Як наслідок органи правосуддя України змінили акцент в кваліфікації злочинів з антидержавницького на терористичний.

Така оцінка знайшла своє відображення й в актах Верховної Ради України, що посилило впевненість органів правосуддя. Так, 22 липня 
2014 р. Верховна Рада ухвалила дві офіційні Заяви у зв'язку з поширенням тероризму на сході України [33]. У цих Заявах представники ДНР та ЛНР називаються терористами, а світова спільнота закликається до визнання «ЛНР» та «ДНР» терористичними організаціями. Разом з тим, паралельно Російська Федерація називається агресором, що окупувала Крим та веде «терористичну війну» на сході України, в тому числі шляхом вбивств мирного населення, тортур, викрадення людей для отримання викупу та збиття цивільного літака.

Надалі український парламент зконцетрувався на останній частині політичної оцінки. Постановою від 27 січня 2015 р. Верховна Рада України офіційно визнала Російську Федерацію державою-агресором та звернулася до світової спільноти із закликом до такого ж визнання [35]. У постанові від 21 квітня 2015 р. Верховна Рада наголосила на численних воєнних злочинах та злочинах проти людяності, описаних статтями 7 і 8 Римського Статуту, вина за які покладена на Російську Федерацію (пп. 3 і 4) [32].

\section{$O O C$}

Остаточна і офіційна оцінка подій на сході України як акту агресії та окупації відбулася на рівні закону лише на початку 2018 р. Законом від 18 січня 2018 р. «Про особливості державної політики із забезпечення державного суверенітету України на тимчасово окупованих територіях у Донецькій та Луганській областях» [36] було офіційно визнано тимчасово окупованими окремі території України у Донецькій та Луганській областях, в межах яких збройні формування та окупаційна адміністрація Російської Федерації здійснюють загальний контроль (cm. 1). Також наголошується на обов'язках та відповідальності Росії за Гаазькими та Женевськими конвенціями щодо дотримання прав цивільного населення (ст. 7).

Якщо керівництво АТО формально здійснювалося СБУ, на що прямо вказували й положення Закону «Про боротьбу з тероризмом», згідно ст. 12 якого управління АТО здійснюється Антитерористичним центром при СБУ [27], то Закон від 18 січня 2018 р. передбачив здійснення Операції об'єднаних сил (ООС) під управлінням Генерального штабу ЗСУ з метою забезпечення національної безпеки і оборони, відсічі і стримування збройної агресії Російської Федерації. Цим фактично й було закладено правову базу для зміни АТО на ООС 
(статті 8-10). Уже 23 березня 2018 р. в СБУ заявили про передачу військовим керівництва воєнною операцією на Донбасі [24]. Варто зауважити, що цьому передувало прийняття нового Закону «Про національну безпеку», який започаткував реформу силових відомств відповідно до стандартів НАТО та розмежував функції СБУ та ЗСУ [26].

Таким чином, хоча й за своїм характером діяльність «ДНР» та «ЛНР» і їх найманців залишалась антидержавницькою та терористичною, на передній план вийшла інша характеристика їх діяльності, яка полягала вже не у особливих цілях та методах, а в зв'язку 3 іноземною державою, що означає підконтрольність та підпорядкованість агресору. Як наслідок, у 2018 р. не тільки політико-дипломатично, але вже й законодавчо, провідною лінією оцінки подій на сході України стала лінія злочинів агресії, воєнних злочинів та частково - злочинів проти людяності.

Однак, як можна простежити 3 наведених вище статистичних даних, органи розслідування в цілому не поспішали оцінювати злочинну діяльність представників «ДНР» та «ЛНР» як злочини агресії та/або воєнні злочини. Так, у 2014 р. було розпочато лише 2 провадження. У подальшому їх кількість відчутно зросла, проте в порівнянні з цифрами терористичних та антидержавних злочинів становила скоріше виняток із загального правила. Це не змінилося навіть у 2018 р., коли було змінено АТО на ООС і на законодавчому рівні було визнано підпорядкованість «ДНР» та «ЛНР» Російській Федерації шляхом концепції «загального контролю». Не вплинуло на цю практику й оголошення воєнного стану з 26 листопада по 26 грудня 2018 р. [18].

Іншими словами, здається, що законодавча оцінка подій на сході України та відповідні політико-дипломатичні заяви України не відображаються в реальній практиці, а зміна АТО на ООС, у підсумку не означали нічого іншого ніж перейменування. За 2018 р. слідчі органи розслідували лише 4 кримінальних справ за статтями про злочини агресії та воєнні злочини, особливо в порівнянні з попередніми роками (2015 - 38, 2016 - 11, 2017 - 21). Це зокрема дисонує положенням міжнародного кримінального права, яким встановлено обов'язок держави, на території якої вчиняються злочини за міжнародним правом, здійснювати їх кримінальне переслідування і покарання [19, с. 82]. 
Пануюча на національному рівні оцінка злочинних діянь лише як сепаратизму чи тероризму справляє враження, що ніби має місце громадянська війна (внутрішній конфлікт). Це грає на руку агресору, який використовує це як демонстрацію своєї непричетності. Тому стійка та чітка позиція України $\epsilon$ визначальною для оцінки його як міжнародного. Для цього не треба чекати рішень міжнародних судів чи інших інституцій, хоч вони і є важливими. Позиція України, як країни на території якої здійснюється агресія та воєнні злочини, має бути відображена на національному рівні - за допомогою всього механізму національної правової системи, всіх іiі ресурсів, і насамперед кримінально-правових. Норми про воєнні злочини та злочини агресії можуть і повинні запрацювати передусім на національному рівні на повну силу.

\section{4. Висновок}

Блукання національної правової системи в пошуках оцінки подій та їх акторів було закономірним. Спершу реакція правозастосовних органів була заснована на зовнішніх, імовірно найбільш видимих ознаках конфлікту, що розпалювався. Очевидною була територіальна спрямованість конфлікту - захоплення влади на місцях та подальше відокремлення від України з імовірним приєднанням до Російської Федерації або без такого. Очевидність цих ознак обумовила первинну оцінку подій як сепаратистських, що в свою чергу було спроектовано на кваліфікацію діянь учасників цих подій як посягань на територіальну цілісність України (ст. 110 КК) та дій, спрямованих на насильницьку зміну чи повалення конституційного ладу або захоплення державної влади (ст. 109 КК).

Встановлення фактичного територіального панування над окремими районами Донецької та Луганської областей та подальший контрнаступ військових українських підрозділів, позначений як «АТО», трансформували цілі учасників незаконних збройних формувань та груп найманців. При збереженні сепаратистських цілей сформувалась мета за будь-яку ціну утримати незаконно захоплені території. У зв'язку з цим у характері поведінки представників самопроголошених республік все більше почали проявлятися ознаки тероризму.

Запроваджена АТО виконала своє головне призначення - локалізувала територію конфлікту, зупинила просування проросійських 
угрупувань та дала час, щоб спробувати зрозуміти гібридну стратегію ворога та вибудувати політику протидії їй. Застосування ж положень кримінального закону про тероризм та «державні злочини» дозволило відносно успішно та в полегшений спосіб протидіяти тим, хто зі зброєю в руках перешкоджав українським підрозділам, шпигував на користь ДНР та ЛНР чи виконував їх злочинні завдання. Однак АТО за своєю природою не могло існувати роками та поширюватися при цьому на територію в кілька десятків тисяч квадратних кілометрів. Тривалість та систематичність протистоянь, політичні та геополітичні чинники в їх основі та їх військовий характер рано чи пізно повинні були привести до визнання аналізованих подій військовим конфліктом. Оскільки ж Росія не визнає свої участі, то й прокуратура і суди України кваліфікують більшість злочинних діянь як тероризм або антидержавні злочини. Переплітання в одному конфлікту дій різних акторів, що ховають свої справжні обличчя, викривляють цілі та наміри, а також використання різних методів і форм боротьби - призводить до неможливості одновекторної (однозначної) оцінки як самого цього конфлікту в цілому, так і відповідних злочинів, які його складають. Конфлікт таким чином стає сумішшю тероризму, сепаратизму, державної зради, агресії та воєнних злочинів.

\section{Список літератури:}

1. «Нафтогаз» виграв арбітраж у Гаазі проти Росії щодо втрати активів у Криму. URL: https://tsn.ua/groshi/naftogaz-vigrav-arbitrazh-u-gaazi-proti-rosiyischodo-vtrati-aktiviv-u-krimu-1305585.html (дата звернення: 31.10.2019).

2. 30 квітня 2018 року розпочалась операція Об’єднаних сил із відсічі та стримування збройної агресії Росії на Донбасі - Президент підписав Указ. URL: http://www.mil.gov.ua/news/2018/04/30/30-kvitnya-2018-roku-rozpochalasoperacziya-obednanih-sil-iz-vidsichi-ta-strimuvannya-zbrojnoi-agresii-rosii-nadonbasi-prezident-pidpisav-ukaz/ (дата звернення: 31.10.2019).

3. Baku declaration and resolutions: adopted by the OSCE Parliamentary Assembly at the twenty-third annual session (Baku, 28 June to 2 July 2014). URL: https://www.oscepa.org/documents/annual-sessions/2014-baku/declaration2/2540-2014-baku-declaration-eng/file (дата звернення: 31.10.2019).

4. Crimea Declaration: Press Statement of the U.S. Department of State on 25 July 2018. URL: https://www.state.gov/secretary/remarks/2018/07/284508.htm (дата звернення: 31.10.2019).

5. International Court of Justice: Order of 19 April 2017. Request for the indication of Provisional Measures. URL: https://www.icj-cij.org/fles/caserelated/166/166-20170419-ORD-01-00-EN.pdf (дата звернення: 31.10.2019). 
6. Koval Dmytro: Ukraine vs. Russland vor dem Internationalen Gerichtshof: Juristische Argumente und politische Erwartungen, in: UKRAINEANALYSEN, 208/2018. S. 2-7. URL: http://laender-analysen.de/ukraine/pdf/ UkraineAnalysen208.pdf (дата звернення: 31.10.2019).

7. Report of the International Court of Justice (1 August 2017-31 July 2018), 63 s. URL: https://www.icj-cij.org/files/annual-reports/2017-2018-en.pdf (дата звернення: 31.10 .2019 ).

8. Report on Preliminary Examination Activities (2015). Report of the Prosecutor of the International Criminal Court to the United Nations. URL: https://www.icc-cpi.int//Pages/item.aspx?name=otp-rep-pe-activities-2015 (дата звернення: 31.10.2019).

9. Report on Preliminary Examination Activities (2016). Report of the Prosecutor of the International Criminal Court to the United Nations. URL: https://www.icc-cpi.int/ Pages/item.aspx?name=161114-otp-rep-PE (дата звернення: 31.10.2019).

10. Report on Preliminary Examination Activities (2018). Report of the Prosecutor of the International Criminal Court to the United Nations. URL: https://www.icc-cpi.int/ Pages/item.aspx?name=181205-rep-otp-PE (дата звернення: 31.10.2019).

11. Resolution 2132 (2016). of the Parliamentary Assembly, 12.10.2016: "Political consequences of the Russian aggression in Ukraine». URL: http://assembly.coe.int/nw/xml/XRef/Xref-XML2HTML-en.asp?fileid=23166 (дата звернення: 31.10.2019).

12. Resolution 2133 (2016) of the Parliamentary Assembly, 12.10.2016: «Legal remedies for human rights violations on the Ukrainian territories outside the control of the Ukrainian authorities». URL: http://assembly.coe.int/nw/xml/XRef/XrefXML2HTML-en.asp?fileid=23167 (дата звернення: 31.10.2019).

13. Resolution of the General Assembly 68/262 on 27 March 2014: «Territorial integrity of Ukraine». URL: https://undocs.org/A/RES/68/262 (дата звернення: 31.10.2019).

14. Resolution of the General Assembly 71/205 on 19 December 2016: «Situation of human rights in the Autonomous Republic of Crimea and the city of Sevastopol (Ukraine)». URL: https://undocs.org/A/RES/71/205 (дата звернення: 31.10.2019).

15. Resolution of the General Assembly 72/190 on 19 December 2017: «Situation of human rights in the Autonomous Republic of Crimea and the city of Sevastopol (Ukraine)». URL: https://www.un.org/en/ga/search/view_doc. asp?symbol=A/RES/72/190 (дата звернення: 31.10.2019).

16. Senatorowa Oksana: Die Ukraine und der Internationale Strafgerichtshof: Der lange Weg zur Gerechtigkeit, in: UKRAINE-ANALYSEN, 208/2018, s. 7-11. URL: http://laender-analysen.de/ukraine/pdf/UkraineAnalysen208.pdf (дата звернення: 31.10.2019).

17. Simon Gerhard. Zusammenbruch und Neubeginn: Die ukrainische Revolution und ihre Feinde. Osteuropa. 2014. № 5-6. S. 9-40.

18. Ukraine stimmt 30-tägigem Kriegsrecht zu. SpiegelOnline. URL: http://www.spiegel.de/politik/ausland/ukraine-parlament-stimmt-30-taegigemkriegsrecht-zu-wegen-russland-konflikt-a-1240564.html (дата звернення: 31.10.2019). 
19. Werle Gerhard: Völkerstrafrecht, 2., neubearbeitete Auflage. Mohr Siebeck Tübingen 2007. $553 \mathrm{~s}$.

20. Висновок Конституційного Суду України у справі за конституційним поданням Президента України про надання висновку щодо відповідності Конституції України Римського Статуту Міжнародного кримінального суду № 3-в/2001, 11.07.2001. URL: https://zakon.rada.gov.ua/laws/show/ v003v710-01?lang=en (дата звернення: 31.10.2019).

21. Захист інвестицій на окупованих територіях. URL: http://yur-gazeta.com/ publications/practice/mizhnarodne-pravo-investiciyi/zahist-investiciy-naokupovanih-teritoriyah.html (дата звернення: 31.10.2019).

22. Заява Верховної Ради України до Міжнародного кримінального суду про визнання Україною юрисдикції міжнародного кримінального суду щодо скоєння злочинів проти людяності вищими посадовими особами держави, які призвели до особливо тяжких наслідків та масового вбивства українських громадян під час мирних акцій протестів у період з 21 листопада 2013 року по 22 лютого 2014 року»: заява Верховної Ради України № 790-VI від 25 лютого 2014 р. URL: https://zakon.rada.gov.ua/laws/show/790-18. (дата звернення: 31.10.2019).

23. MBC: Події в Криму є окупацією з боку Pociï. URL: https://www.unian.ua/ crime/890989-mvs-podiji-v-krimu-e-okupatsieyu-z-boku-rosiji.html (дата звернення: 31.10.2019).

24. Міноборони: АТО триватиме паралельно з операцією Об'єднаних сил до указу президента. Радіо Свобода. URL: https://www.radiosvoboda.org/a/ news/29130260.html (дата звернення: 31.10.2019).

25. Парубій вважає, що сьогодні провокації в Криму влаштовують російські спецслужби. URL: https://www.unian.ua/politics/890861-parubiy-vvajaescho-sogodni-provokatsiji-v-krimu-vlashtovuyut-rosiyski-spetsslujbi.html (дата звернення: 31.10 .2019$)$.

26. Президент підписав закон про нацбезпеку. УКРІНФОРМ. URL: https://www.ukrinform.ua/rubric-polytics/2493176-prezident-pidpisav-zakonpro-nacbezpeku.html (дата звернення: 31.10.2019).

27. Про боротьбу з тероризмом : Закон України № 638-IV від 20.03.2003. URL: https://zakon.rada.gov.ua/laws/show/638-15 (дата звернення: 31.10.2019).

28. Про внесення змін до Конституції України (щодо правосуддя) : Закон України № 1401-VIII від 02.06.2016. URL: https://zakon.rada.gov.ua/laws/ show/1401-19\#n6 (дата звернення: 31.10.2019).

29. Про Голову Верховної Ради України : постанова Верховної Ради України № 748-VII, 22.02.2014. URL: http://zakon4.rada.gov.ua/laws/show/748-vii (дата звернення: 31.10.2019).

30. Про забезпечення прав і свобод громадян та правовий режим на тимчасово окупованій території України: Закон України № 1207-VII від 15.04.2014. URL: http://zakon.rada.gov.ua/laws/show/1207-18 (дата звернення: 31.10.2019).

31. Про Заяву Верховної Ради України "Про визнання Україною юрисдикції Міжнародного кримінального суду щодо скоєння злочинів проти людяності та воєнних злочинів вищими посадовими особами Російської Федерації та керівниками терористичних організацій "ДНР" та "ЛНР", які 
призвели до особливо тяжких наслідків та масового вбивства українських громадян»: постанова Верховної Ради України № 145-VIII від 04.02.2015. URL: https://zakon.rada.gov.ua/laws/show/145-19 (дата звернення: 31.10.2019).

32. Про Заяву Верховної Ради України «Про відсіч збройній агресії Російської Федерації та подолання ії наслідків» : постанова Верховної Ради України № 337-VIII від 21.04.2015. URL: http://zakon.rada.gov.ua/laws/ show/337-19 (дата звернення: 31.10.2019).

33. Про Заяву Верховної Ради України «Про трагічну загибель людей внаслідок терористичного акту над територією України» : постанова Верховної Ради України № 1596-VII від 22.07.2014. URL: http://zakon.rada.gov.ua/laws/ show/1596-18 (дата звернення: 31.10.2019).

34. Про Заяву Верховної Ради України «Щодо протидії поширенню підтримуваного Російською Федерацією міжнародного тероризму»: постанова ВерховноїРади України№ 1597-VIІвід22.07.2014.URL:http://zakon.rada.gov.ua/ laws/show/1597-18. (дата звернення: 31.10.2019).

35. Про Звернення Верховної Ради України до Організації Об'єднаних Націй, Європейського Парламенту, Парламентської Асамблеї Ради Європи, Парламентської Асамблеї НАТО, Парламентської Асамблеї ОБСЄ, Парламентської Асамблеї ГУАМ, національних парламентів держав світу про визнання Російської Федерації державою-агресором : постанова Верховної Ради України № 129-VIII від 27.01.2015. URL: http://zakon.rada.gov.ua/laws/ show/129-19 (дата звернення: 31.10.2019).

36. Про особливості державної політики із забезпечення державного суверенітету України на тимчасово окупованих територіях у Донецькій та Луганській областях: Закон України № 2268-VIII від 18-01.2018. URL: http://zakon.rada.gov.ua/laws/show/2268-19 (дата звернення: 31.10.2019).

37. Про рішення Ради національної безпеки і оборони України від 13 квітня 2014 року «Про невідкладні заходи щодо подолання терористичної загрози і збереження територіальної цілісності України» : Указ Президента України від 14 квіт. 2014 р. URL: http://zakon2.rada.gov.ua/laws/show/405/2014 (дата звернення: 31.10.2019).

38. Про рішення Ради національної безпеки і оборони України від 30 квітня 2018 року «Про широкомасштабну антитерористичну операцію в Донецькій та Луганській областях» : Указ Президента України № 116/2018, 30.04.2018. URL: http://zakon.rada.gov.ua/laws/show/116/2018 (дата звернення: 31.10.2019).

39. Про самоусунення Президента України від виконання конституційних повноважень та призначення позачергових виборів Президента України: постанова Верховної Ради України № 757-VII, 22.02.2014. URL: http://zakon2.rada.gov.ua/laws/show/757-18 (дата звернення: 31.10.2019).

40. Про текст Конституції України в редакції 28 червня 1996 року, із змінами і доповненнями, внесеними законами України від 8 грудня 2004 року № 2222-IV, від 1 лютого 2011 року № 2952-VI, від 19 вересня 2013 року № 586-VII: постанова Верховної Ради України № 750-VII, 22.02.2014. URL: http://zakon2.rada.gov.ua/laws/show/750-18 (дата звернення: 31.10.2019).

41. Римський статут міжнародного кримінального суду. URL: https://zakon.rada.gov.ua/laws/show/995_588 (дата звернення: 31.10.2019). 
42. Турчинов: Росія розігрує в Криму абхазький сценарій. URL: https://www.unian.ua/politics/891388-turchinov-rosiya-rozigrue-v-krimuabhazkiy-stsenariy.html (дата звернення: 31.10.2019).

43. У Свросуді знаходиться п'ять справ «Україна проти Росії». URL: https://www.ukrinform.ua/rubric-polytics/2633659-u-evrosudi-znahoditsapat-sprav-ukraina-proti-rosii.html (дата звернення: 31.10.2019).

44. Україна подала до арбітражу в Гаазі меморандум про порушення Росією морського права. URL: https://www.dw.com/ukyкраїна-подала-до-арбітражув-гаазі-меморандум-про-порушення-росією-морського-права/а-42646782 (дата звернення: 31.10.2019).

45. Шість тонн доказів проти Росії: що передала Україна до Міжнародного суду ООН. Європейська правда. URL: https://www.eurointegration.com.ua/ articles/2018/06/12/7083003/ (дата звернення: 31.10.2019).

\section{References:}

1. Naftohaz vygrav arbitrazh u Gaazi proty Rosiji shchodo vtraty aktyviv u Krymu [Naftogaz wins arbitration in The Hague against Russia over asset loss in Crimea]. URL: https://tsn.ua/groshi/naftogaz-vigrav-arbitrazh-u-gaazi-protirosiyi-schodo-vtrati-aktiviv-u-krimu-1305585.html (accessed 31 Oktober, 2019). (in Ukrainian)

2. 30 Kvitnia 2018 roku rozpochalas Operatsiia Obiednanykh Syl iz vidsichi ta strymuvannia zbroinoi ahresii Rosii na Donbasi - Prezydent pidpysav ukaz [On April 30, 2018, a joint operation to repel and curb Russia's armed aggression in the Donbass began - the president signed the decree]. URL: http://www.mil.gov. ua/news/2018/04/30/30-kvitnya-2018-roku-rozpochalas-operacziya-obednanih-siliz-vidsichi-ta-strimuvannya-zbrojnoi-agresii-rosii-na-donbasi-prezident-pidpisavukaz/ (accessed 31 Oktober, 2019). (in Ukrainian)

3. Baku declaration and resolutions: adopted by the OSCE Parliamentary Assembly at the twenty-third annual session (Baku, 28 June to 2 July 2014). URL: https://www.oscepa.org/documents/annual-sessions/2014-baku/declaration2/2540-2014-baku-declaration-eng/file (accessed 31 Oktober, 2019).

4. Crimea Declaration: Press Statement of the U.S. Department of State on 25 July 2018. URL: https://www.state.gov/secretary/remarks/2018/07/284508.htm (accessed 31 Oktober, 2019).

5. International Court of Justice: Order of 19 April 2017. Request for the indication of Provisional Measures. URL: https://www.icj-cij.org/fles/caserelated/166/166-20170419-ORD-01-00-EN.pdf (accessed 31 Oktober, 2019).

6. Koval Dmytro: Ukraine vs. Russland vor dem Internationalen Gerichtshof: Juristische Argumente und politische Erwartungen, in: UKRAINE-ANALYSEN, 208/2018. URL: http://laender-analysen.de/ukraine/pdf/UkraineAnalysen208.pdf (accessed 31 Oktober, 2019). (in German)

7. Report of the International Court of Justice (1 August 2017 - 31 July 2018), 63 s. URL: https://www.icj-cij.org/files/annual-reports/2017-2018-en.pdf (accessed 31 Oktober, 2019). 
8. Report on Preliminary Examination Activities (2015). Report of the Prosecutor of the International Criminal Court to the United Nations. URL: https://www.icc-cpi.int//Pages/item.aspx?name=otp-rep-pe-activities-2015 (accessed 31 Oktober, 2019).

9. Report on Preliminary Examination Activities (2016). Report of the Prosecutor of the International Criminal Court to the United Nations. URL: https://www.icc-cpi.int/ Pages/item.aspx?name=161114-otp-rep-PE (accessed 31 Oktober, 2019).

10. Report on Preliminary Examination Activities (2018). Report of the Prosecutor of the International Criminal Court to the United Nations. URL: https://www.icc-cpi.int/ Pages/item.aspx?name=181205-rep-otp-PE (accessed 31 Oktober, 2019).

11. Political consequences of the Russian aggression in Ukraine: Resolution 2132 (2016) of the Parliamentary Assembly, 12.10.2016. URL: http://assembly.coe.int/nw/ $\mathrm{xml} / \mathrm{XRef} / \mathrm{Xref}$-XML2HTML-en.asp?fileid=23166 (accessed 31 Oktober, 2019).

12. Legal remedies for human rights violations on the Ukrainian territories outside the control of the Ukrainian authorities: Resolution 2133 (2016) of the Parliamentary Assembly, 12.10.2016. URL: http://assembly.coe.int/nw/xml/XRef/ Xref-XML2HTML-en.asp?fileid=23167 (accessed 31 Oktober, 2019).

13. Territorial integrity of Ukraine: Resolution of the General Assembly 68/262 on 27 March 2014. URL: https://undocs.org/A/RES/68/262 (accessed 31 Oktober, 2019).

14. Situation of human rights in the Autonomous Republic of Crimea and the city of Sevastopol (Ukraine): Resolution of the General Assembly 71/205 on 19 December 2016. URL: https://undocs.org/A/RES/71/205 (accessed 31 Oktober, 2019).

15. Situation of human rights in the Autonomous Republic of Crimea and the city of Sevastopol (Ukraine): Resolution of the General Assembly 72/190 on 19 December 2017. URL: https://www.un.org/en/ga/search/view_doc.asp?symbol= A/RES/72/190 (accessed 31 Oktober, 2019).

16. Senatorowa Oksana: Die Ukraine und der Internationale Strafgerichtshof: Der lange Weg zur Gerechtigkeit, in: UKRAINE-ANALYSEN, 208/2018. URL: http://laender-analysen.de/ukraine/pdf/UkraineAnalysen208.pdf (accessed 31 Oktober, 2019). (in German)

17. Simon Gerhard. Zusammenbruch und Neubeginn. Die ukrainische Revolution und ihre Feinde. Osteuropa. 2014. № 5-6. S. 9-40. (in German)

18. Ukraine stimmt 30-tägigem Kriegsrecht zu. URL: http://www.spiegel.de/ politik/ausland/ukraine-parlament-stimmt-30-taegigem-kriegsrecht-zu-wegenrussland-konflikt-a-1240564.html (accessed 31 Oktober, 2019). (in German)

19. Werle Gerhard. Völkerstrafrecht. 2., neubearbeitete Auflage. Mohr Siebeck Tübingen. 2007. 553 s. (in German)

20. Vysnovok Konstytutsiinoho Sudu Ukrainy u spravi za konstytutsiinym podanniam prezydenta Ukrainy pro nadannia vysnovku shchodo vidpovidnosti Konstytutsii Ukrainy Rymskoho Statutu Mizhnarodnoho kryminalnoho sudu № 3-в/2001, 11.07.2001 [Opinion of the Constitutional Court of Ukraine in the case on the constitutional submission of the President of Ukraine on the opinion on the conformity of the Constitution of Ukraine with the Rome Statute of the International Criminal Court]. URL: https://zakon.rada.gov.ua/laws/show/ v003v710-01?lang=en (accessed 31 Oktober, 2019). (in Ukrainian) 
21. Zahyst investycij na okupovanych terytorijach [Protection of investments in the occupied territories]. URL: http://yur-gazeta.com/publications/practice/ mizhnarodne-pravo-investiciyi/zahist-investiciy-na-okupovanih-teritoriyah.html (accessed 31 Oktober, 2019). (in Ukrainian)

22. Zajava Verchovnoji Rady Ukrajiny do Mizhnarodnoho kryminalnoho sudu pro vyznannja Ukrajinoju jurysdykciji mizhnarodnoho kryminalnoho sudu shchodo skojennja zlochyniv proty ljudjanosti vyshchymy posadovymy osobamy derzhavy, jaki pryzvely do osoblyvo tjazhkych naslidkiv ta masovoho vbyvstva ukrajinskych hromadjan pid chas myrnych akcij protestiv u period z 21 lystopada 2013 roku po 22 ljutoho 2014 roku: zajava Verchovnoji Rady Ukrajiny № 790-VII, 25.02.2014. URL: https://zakon.rada.gov.ua/laws/show/790-18 (accessed 31 Oktober, 2019). (in Ukrainian)

23. MVS: Podiji v Krymu je okupacijeju z boku Rosiji [Ministry of Internal Affairs: Events in Crimea are occupation by Russia]. URL: https://www.unian.ua/ crime/890989-mvs-podiji-v-krimu-e-okupatsieyu-z-boku-rosiji.html (accessed 31 Oktober, 2019). (in Ukrainian)

24. Minoborony: ATO tryvatyme paralelno z operacijeju Objednanych syl do ukazu prezydenta [Ministry of Defence: ATO will continue in parallel with the Joint Force Operation]. URL: https://www.radiosvoboda.org/a/news/29130260.html (accessed 31 Oktober, 2019). (in Ukrainian)

25. Parubij vvazhaje, shcho sohodni provokaciji v Krymu vlashtovujut rosijski specsluzhby [Parubiy considers that provocations in Crimea are arranged by Russian special services today]. URL: https://www.unian.ua/politics/890861parubiy-vvajae-scho-sogodni-provokatsiji-v-krimu-vlashtovuyut-rosiyskispetsslujbi.html (accessed 31 Oktober, 2019). (in Ukrainian)

26. Prezydent pidpysav zakon pro nacbezpeku [The President signed the Law on National Security]. URL: https://www.ukrinform.ua/rubric-polytics/2493176-prezidentpidpisav-zakon-pro-nacbezpeku.html (accessed 31 Oktober, 2019). (in Ukrainian)

27. Pro borotbu z teroryzmom [On the fight against terrorism]: Zakon Ukrajiny № 638-IV, 20.03.2003. URL: http://zakon.rada.gov.ua/laws/show/638-15\#n244 (accessed 31 Oktober, 2019). (in Ukrainian)

28. Pro vnesennia zmin do Konstytutsii Ukrainy (shchodo pravosuddia) [On Amendments to the Constitution of Ukraine (concerning Justice)]. URL: https://zakon.rada.gov.ua/laws/show/1401-19 (accessed 31 Oktober, 2019). (in Ukrainian)

29. Pro Holovu Verchovnoji Rady Ukrajiny [About the Head of the Verkhovna Rada of Ukraine]: postanova Verkhovnoi Rady Ukrainy № 748-VII, 22.02.2014. URL: http:// zakon4.rada.gov.ua/laws/show/748-vii (accessed 31 Oktober, 2019). (in Ukrainian)

30. Pro zabezpecchennja prav i svobod hromadjan ta pravovyj rezhym na tymchasovo okupovanij terytoriji Ukrajiny [On ensuring the rights and freedoms of citizens and the legal regime in the temporarily occupied territory of Ukraine]: Zakon Ukrajiny 1207-VII, 15.04.2014. URL: http://zakon.rada.gov.ua/laws/ show/1207-18 (accessed 31 Oktober, 2019). (in Ukrainian)

31. Pro Zajavu Verchovnoji Rady Ukrajiny «Pro vyznannja Ukrajinoju jurysdykciji Mizhnarodnoho kryminalnoho sudu shchodo skojennja zlochyniv proty 
ljudjanosti ta vojennyx zlochyniv vyshchymy posadovymy osobamy Rosijskoji Federaciji ta kerivnykamy terorystychnyx orhanizacij «DNR» ta «LNR», jaki pryzvely do osoblyvo tjazhkyx naslidkiv ta masovoho vbyvstva ukrajinskych hromadjan»: postanova Verchovnoji Rady Ukrajiny № 145-VIII, 04.02.2015. URL: https:// zakon.rada.gov.ua/laws/show/145-19 (accessed 31 Oktober, 2019). (in Ukrainian)

32. Pro Zajavu Verchovnoji Rady Ukrajiny „Pro vidsich zbrojnij ahresiji Rosijskoji Federaciji ta podolannja jiji naslidkiv" [On the Statement of The Verkhovna Rada of Ukraine "On Repelling the Armed Aggression of Russia and Overcoming its Consequences"]: postanova 337-VIII, 21.04.2015. URL: http:// zakon.rada.gov.ua/laws/show/337-19 (accessed 31 Oktober, 2019). (in Ukrainian)

33. Pro trahichnu zahybel ljudej vnaslidok terorystychnoho aktu nad terytorijeju Ukrajiny [About the tragic death of people as a result of a terrorist act on the territory of Ukraine]: postanova 1596-VII, 22.07.2014. URL: http://zakon.rada. gov.ua/laws/show/1596-18 (accessed 31 Oktober, 2019). (in Ukrainian)

34. Pro Zajavu Verchovnoji Rady Ukrajiny „Shchodo protydiji poshyrennju pidtrymuvanoho Rosijskoju Federacijeju mizhnarodnoho teroryzmu“ [On the Statement of the Verkhovna Rada of Ukraine "On Countering the Spread of International Terrorism Supported by the Russian Federation"]: postanova 1597-VII, 22.07.2014. URL: http://zakon.rada.gov.ua/laws/show/1597-18 (accessed 31 Oktober, 2019). (in Ukrainian)

35. Pro Zvernennja Verchovnoji Rady Ukrajiny do Orhanizaciji Objednanych Nacij, Jevropejskoho Parlamentu, Parlamentskoji Asambleji Rady Jevropy, Parlamentskoji Asambleji NATO, Paramentskoji Asambleji OBSJe, Parlamentskoji Asambleji HUAM, nacionalnych parlamentiv derzhav svitu pro vyznannja Rosijskoji Federaciji derzhavoju-ahresorom: postanova 129-VIII, 27.01.2015. URL: http:// zakon.rada.gov.ua/laws/show/129-19 (accessed 31 Oktober, 2019). (in Ukrainian)

36. Pro osoblyvosti derzhavnoji polityky iz zabezpechennja derzhavnoho suverenitetu Ukrajiny na tymchasovo okupovanyx terytorijach u Doneckij ta Luhanskij oblastjach [On the features of the state policy on ensuring the state sovereignty of Ukraine in the temporarily occupied territories in Donetsk and Luhansk regions]: Zakon Ukrajiny № 2268-VIII, 18-01.2018. URL: http://zakon. rada.gov.ua/laws/show/2268-19. (accessed 31 Oktober, 2019). (in Ukrainian)

37. Pro rishennia Rady Natsionalnoi bezpeky i oborony Ukrainy vid 13 kvitnia 2014 roku pro nevidkladni zakhody shchodo podolannia terorystychnoi zahrozy i zberezhennia terytorialnoi tsilisnosti Ukrainy [On the decision of the National Security and Defense Council of 13 April 2014 "On urgent measures to overcome the terrorist threat and preserve the territorial integrity of Ukraine"]: Ukaz Prezydenta Ukrainy № 405/2014, 14.04.2014. URL: http://zakon2.rada.gov.ua/ laws/show/405/2014 (accessed 31 Oktober, 2019). (in Ukrainian)

38. Pro shyrokomashtabnu antyterorystychnu operaciju v Doneckij ta Luhanskij oblastjach [On a large-scale anti-terrorist operation in Donetsk and Luhansk regions]: Ukaz Prezydenta Ukrainy № 116/2018, 30.04.2018. URL: http://zakon. rada.gov.ua/laws/show/116/2018 (accessed 31 Oktober, 2019). (in Ukrainian)

39. Pro samousunennja Prezydenta Ukrajiny vid vykonannja konstytucijnych povnovazhen ta pryznachennja pozacherhovych vyboriv Prezydenta Ukrajiny 
[On the self-removal of the President of Ukraine from the exercise of constitutional powers and the appointment of snap elections of the President of Ukraine]: postanova Verkhovnoi Rady Ukrainy № 757-VII, 22.02.2014. URL: http:// zakon2.rada.gov.ua/laws/show/757-18 (accessed 31 Oktober, 2019). (in Ukrainian)

40. Pro tekst Konstytuciji Ukrajiny v redakciji 28 chervnja 1996 roku, iz zminamy i dopovnenn-jamy, vnesenymy zakonamy Ukrajiny vid 8 hrudnja 2004 roku 2222-IV, vid 1 ljutoho 2011 roku 2952-VI, vid 19 veresnja 2013 roku 586-VII [On the text of the Constitution of Ukraine as amended on June 28, 1996, on December 8, 2004 No. 2222-IV, on February 1, 2011 No. 2952-VI, on September 19, 2013 No. 586-VII]: postanova Verkhovnoi Rady Ukrainy № 750-VII, 22.02.2014. URL: http://zakon2.rada.gov.ua/laws/show/750-18 (accessed 31 Oktober, 2019). (in Ukrainian)

41. Rymskyi Statut Mizhnarodnoho Kryminalnoho Sudu [Rome Statute of the International Criminal Court]. URL: https://zakon.rada.gov.ua/laws/show/995_588 (accessed 31 Oktober, 2019). (in Ukrainian)

42. Turchynov: Rosija rozihruje v Krymu abchazkyj scenarij [Turchynov: Russia is playing out the Abkhaz scenario in Crimea]. URL: https://www.unian.ua/ politics/891388-turchinov-rosiya-rozigrue-v-krimu-abhazkiy-stsenariy.html (accessed 31 Oktober, 2019). (in Ukrainian)

43. U yevrosudi znakhodytsia piat sprav «Ukraina proty Rosii» [There are five cases ,, Ukraine vs Russia” in the European Court]. URL: https://www.ukrinform.ua/ rubric-polytics/2633659-u-evrosudi-znahoditsa-pat-sprav-ukraina-proti-rosii.html (accessed 31 Oktober, 2019). (in Ukrainian)

44. Ukrajina podala do arbitrazhu v Gaazi memorandum pro porushennja Rosijeju morskoho prava [Ukraine has submitted to the Hague arbitration memorandum of violation of maritime law by Russia]. URL: https://www.dw.com/ ukукраїна-подала-до-арбітражу-в-гаазі-меморандум-про-порушення-росієюморського-права/a-42646782 (accessed 31 Oktober, 2019). (in Ukrainian)

45. Shist tonn dokaziv proty Rosiji: shcho peredala Ukrajina do Mizhnarodnoho sudu OON [Six Tons of Evidence Against Russia: What Has Ukraine Transferred to the International Court of Justice]. URL: https://www.eurointegration.com.ua/ articles/2018/06/12/7083003/ (accessed 31 Oktober, 2019). (in Ukrainian) 